\title{
The adoration of a map: Reflections on a genome metaphor
}

\author{
HUB ZWART ${ }^{1}$
}

\section{Introduction}

On June 26, 2000, President Clinton, together with Francis Collins and Craig Venter, solemnly announced, from the East Room of the White House, that the grand effort to sequence the human genome, the Human Genome Project (HGP), was rapidly nearing its completion. The formal press release covering this event reads like the minutes of a stately royal or even religious ceremony, with all the associated pomp and circumstance. ${ }^{2}$ The key players present are all formally introduced and acknowledged, and the bulk of the meeting is devoted to a series of formally staged and highly ritualized dialogues, notably between two pairs of speakers, Bill Clinton and Tony Blair (with the latter participating by satellite, thus adding to the dramaturgic setting of the meeting as a both present and absent face and voice), and Francis Collins and Craig Venter. All leading individuals and leading countries seemed to congregate gracefully in a harmonious celebration, as if a victory had been won or a major achievement was being formally commemorated; as if humankind would now finally be released from its plagues, notably cancer (humanity's enemy number one). Conflicts, feuds, rivalries and various instances of strife were all temporarily reconciled, as in a Shakespearean play. ${ }^{3}$ The head of state, positioning himself at the centre of the universe and at the summit of history as it were, flanked by two of his most steadfast and valiant knights, or trusted aides, stepped forward to formally address ambassadors and representatives from around the globe. Symbolism abounded. The event was framed as a crucial marker in the history of both humanity and knowledge by explicitly connecting the completion of the HGP with a number of already acknowledged and established scientific highlights, from the work of Galileo, via Newton ("we stand on many shoulders", as Collins phrased it) up to the 1953 Nature article by Watson and Crick.

Yet the "wars"4 and conflicts temporarily resolved by this highly visible and abundantly annotated event were not only conflicts between competing research methods, research strategies and research teams, but also conflicts between competing metaphors. In the course of the HGP, metaphors had become crucially important in framing and conveying what the HGP was really about. They had proved themselves to be of key importance when it came to defining and explaining the project's significance for both science and society. Powerful images and metaphors had been deployed in order to secure unprecedented amounts of funding, on the one hand by comparing the HGP to other big technoscientific projects such as space travel, high energy physics and the atomic bomb, ${ }^{5}$ and on the other hand through the suggestion that, once we have our "blueprint" 6 , "code of codes", "parts list", etc. available, cancer genes will no longer have a place to hide, an idea that was already present in the first publications advocating the launching of a mammoth project in biology to reveal the human sequence. ${ }^{8}$ Walter Gilbert, a visionary Nobel laureate who played a

Genomics, Society and Policy, Vol.5, No.3 (2009) ISSN: 1746-5354

(C) ESRC Genomics Network. 
decisive role in the preparatory stages of the HGP, had his own favourite metaphor to arouse enthusiasm for the project, staging the human sequence as the "Holy Grail" of human genetics. ${ }^{9}$ Yet, human genome metaphors tend to be controversial, often because of their deterministic connotations, apparently failing to acknowledge the environmental factors that mould us into what we are. In fact, the history of the HGP has been a history of competition in various ways, but not only between the publicly funded consortium led by Francis Collins and its privately funded contender Celera, led by Craig Venter. It was also a competition between metaphors. Indeed, one could read the history of the HGP, of which the press conference constituted a final apotheosis-like "scene", as a drama in which the main protagonists, the key dramatis personae, had been metaphors rather than human individuals. On June 26, 2000, metaphors more than anything else enter and exeunt the East Room stage.

This article sets out to analyze this conflict or clash of metaphors, firmly embedded within the HGP but culminating at the press conference. It is part of a series of articles, devoted to assessing the significance and import of the HGP, ${ }^{10}$ the role of the key protagonists involved ${ }^{11}$ and of the basic metaphors or images that structured it. ${ }^{12}$ Yet, whereas these other publications focus either on the history of the HGP or on subsequent events, this analysis explicitly focuses on the press conference as a (albeit highly disputed and controversial) milestone and turning point. In terms of methodology, the verbatim account of the press conference is subjected to a process of close reading devoted to revealing and assessing the symbolical and imaginary structures of the text. The relevance of this exercise builds on the fact that the meaning and significance of the HGP for science and society is both framed and contested through the dominant metaphors at work.

\section{Enter the metaphors}

In the statements made at the press conference, a number of established metaphors that had come to be associated with the HGP over the years were explicitly mentioned ("welcomed"). Indeed, similar to the key individuals present, these key metaphors were likewise formally introduced and acknowledged, as it were, for the role they had come to play in the process. The genome was subsequently and formally baptized as the "language of life", as our "genetic code", "the working blueprint of mankind", the "book of life", our "instruction book", our "common inheritance", our "essence". A whole train of metaphors, each with its own history of rise and decline, thus assembled side by side with the human actors present. ${ }^{13}$ Yet, the dominant metaphor that won the day, introduced with remarkable emphasis right at the beginning of the ceremony, and allowed to shape the whole narrative from there, was the map metaphor, supported by a series of images and concerns closely associated with it. Indeed, rereading the protocol of the press conference 10 years later it is still quite striking how President Clinton, after a number of formal acknowledgements of human individuals (the chorus members as it were), suddenly proceeds to present the human genome sequence in the form of a metaphor, as follows (my italics):

Genomics, Society and Policy, Vol.5, No.3 (2009) ISSN: 1746-5354

(C) ESRC Genomics Network. 
Nearly two centuries ago, in this room, on this floor, Thomas Jefferson and a trusted aide spread out a magnificent map - a map Jefferson had long prayed he would see in his lifetime. The aide was Meriwether Lewis and the map was the product of a courageous expedition across the American frontier, all the way to the Pacific. It was a map that defined the contours and forever expanded the frontiers of our continent and our imagination. Today, the world is joining us here in the East Room to behold a map of even greater significance. We are here to celebrate the completion of the first survey of the entire human genome. Without a doubt, this is the most important, most wondrous map ever produced by humankind.

Although genome sequencing had been compared to map-making before, ${ }^{14,15,16}$ the metaphor had never been fleshed out in such detail. ${ }^{17}$ When reading and contemplating this crucial passage, it dawns on us that the key figure of the ceremony, the true and only 'sovereign' as it were, the true focus of attention, of all the euphoria and expectation, is neither Clinton (whose mandate in fact was about to expire), nor Blair, nor Collins, nor Venter, nor any of the other human protagonists, but an imaginary, metaphorical entity: a "map", an almost Lacanian "thing" that was not really, physically, tangibly there, but that nonetheless emerged as the focus of intentionality and attention, structuring the whole discourse, the whole mise-en-scène of science and science politics, spread out by means of a series of symbolic gestures as an (imaginary) object to which a remarkable occasion was wholly devoted, as the ultimate object of all our converging scientific, political and economic desires, the ultimate object of gratification, the final redemption of our efforts and expense. All of a sudden, it is clear why the press conference was organized 'prematurely' as it were, months, even years before the HGP was really 'finished'. In fact, rather than premature timing, this may be seen as an appropriate decision, as such a map will never be really there in a complete, finished and tangible form. Its destiny is to continue to serve as a virtual structure, something that 'we' in a collaborative vein will continue to work on. Representatives of all the sciences thus assembled - and again, the sciences involved are formally introduced and acknowledged during the press conference as if they had been key players ${ }^{18}$ - formally came together in a solemn adoration of this map.

Seen from this perspective, the June 2000 event is reminiscent of a somewhat similar event, depicted by a famous altarpiece, 'The adoration of the Lamb', on display in Ghent Cathedral and finished more than five centuries before by the brothers Van Eyck, the central panel of which is reproduced below. As the Van Eyck altarpiece brings together hermits, pilgrims, saints, burghers and nobility in a joint celebration, the White House press conference brought together scientists, journalists, policymakers and heads of state in a similar gathering. They regard themselves as representatives of humanity ("Today, the world is joining us to behold a map..."), staring at and beholding a sublime object. The Van Eyck representation of this event is generally regarded as one of the most wondrous and encompassing artwork ever made. Likewise, the human genome map is presented almost as a scientific work of art, the culmination of a scientific journey. Like the lamb on the altarpiece, the map is

Genomics, Society and Policy, Vol.5, No.3 (2009) ISSN: 1746-5354

(C) ESRC Genomics Network. 
expected to save mankind from all evil, notably by erasing cancer and a number of degenerative diseases. Indeed, it is claimed that, due to this "most wondrous map... Our children's children will know the term cancer only as a constellation of stars"! And one might even argue that the 24 compartmented scenes that constitute the late medieval altarpiece all but correspond with the 23 pairs of chromosomes that serve as carriers for the human genome... But let us have a closer look.

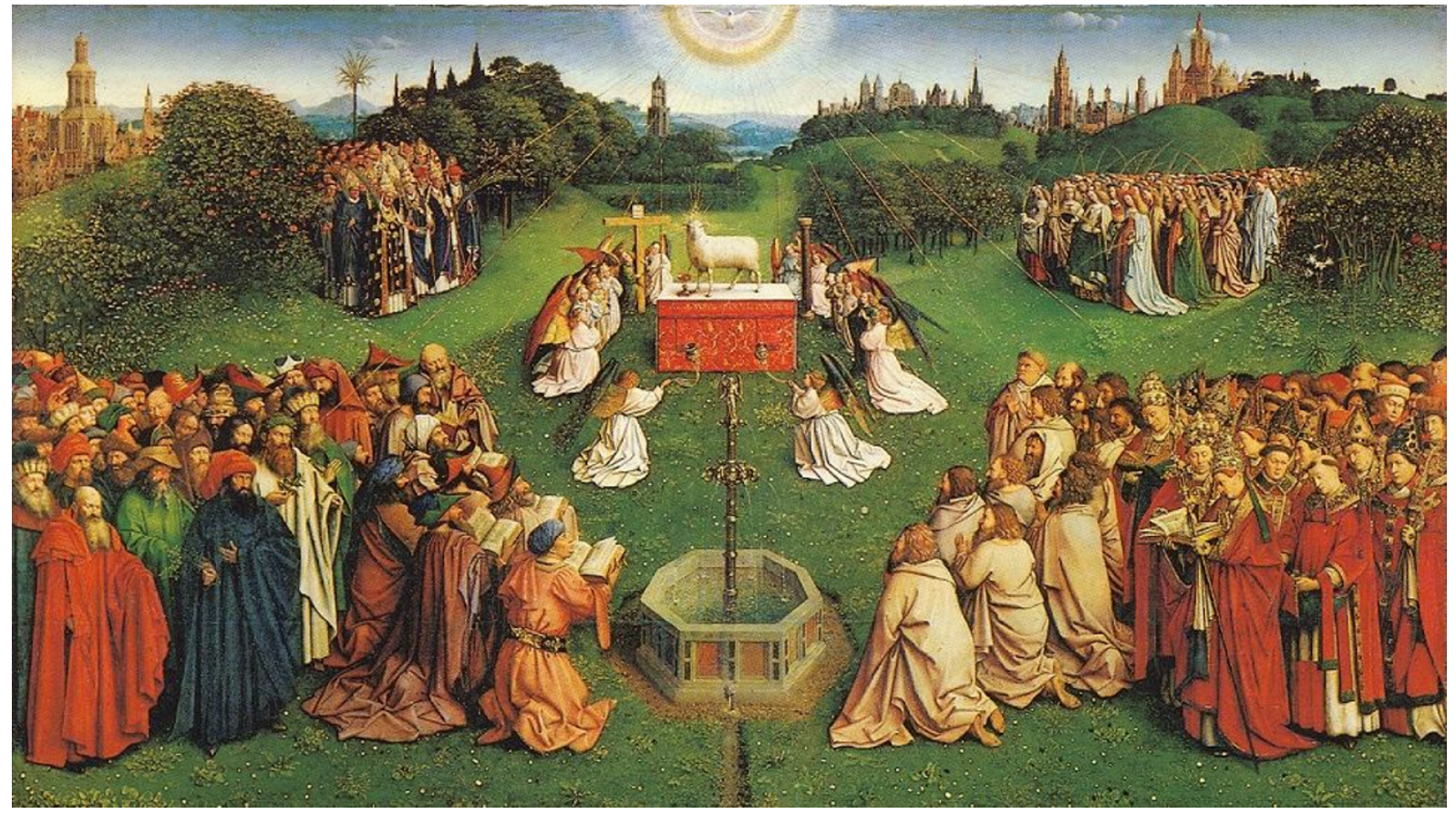

\section{The "wondrous map" revealed}

There is a substantial amount of religious language used at the press conference, notably in the form of adjectives connected with the central genome metaphors deployed ("wondrous" map, "miraculous" code, a book "previously known only to God", etc.). Before becoming entangled in possible interpretations, however, let us first of all reread as closely and explicitly as possible, letter by letter as it were, how the metaphor of the map is introduced and used.

In the key passage cited above, where the map metaphor itself is spread out, as it were, we clearly notice a series of gestures of identification. Two "couples" are presented, similar in function but divorced from one another by a time span of almost two centuries. Both consist of a sovereign (a President) and his "trusted aide", that is: a head of state and his mapmaker, his prime surveyor. Clearly, while Clinton readily identifies himself with Thomas Jefferson, Francis Collins is associated or paired with Meriwether Lewis. Due to the combined efforts of both pairs, distanced from one another by two eventful centuries during which the United States emerged as the world's leading nation, the astonishing results of a survey of an unknown territory are now presented, a territory about to be claimed. ${ }^{19}$ The survey of the human genome

Genomics, Society and Policy, Vol.5, No.3 (2009) ISSN: 1746-5354

(C) ESRC Genomics Network. 
mirrors the survey of the North-West territories, conducted almost two centuries before.

In his own statement, Francis Collins is eager to follow Clinton's lead and to elaborate this comparison (this metaphor) still further. For Collins, the map-making exercise is connected with a "voyage of exploration into the unknown ... a truly unprecedented voyage". Yet, rather than to a distant realm, beyond the frontiers, the new voyage, the new survey is a voyage "into ourselves". Thus, the map of an external macro-realm outside the realm of civilization, produced by Lewis and his team, and supported by Jefferson, is now complemented by a map of an internal micro-realm, our own genome. Nonetheless, our Self, our physical 'interior', can also apparently be regarded as a territory that lay waiting to be mapped.

That the map metaphor is not merely a rhetorical device but rather the core idea that structures Clinton's and Collins' statements becomes clear when we notice the extent to which this metaphor is elaborated by both speakers, in various directions. First of all, in Clinton's speech, the map is important because it opens up a number of "majestic horizons", emerging at the edges of the landscape being mapped, and defining its structure and contours. The first "horizon" is the finished, error-free "final draft" - a somewhat ambiguous and therefore mystical 'object', for how can a 'draft' ever be "final'? The second "horizon" is the identification, on the basis of this map, of "every human gene" present in the surveyed landscape. Once again, this horizon invokes a suggestion of completion, an almost eschatological concept somewhat at odds with the idea of science, as in science nothing ever seems to be really and fully completed, but also at odds with the idea of a horizon as such, as a fluid contour bound to retreat forever. But I we will come back to the HGP's struggle with the concept of 'completion' in more detail later.

The connection between maps and power, and between map-making and warfare is elaborated in quite some detail. Indeed, the link between map-making and the military is a very old and solid one. Soldiers since time immemorial have been in need of (and very often even produce) reliable and powerful maps. And this is what the human genome sequence provides. It is the result of a triumphant "expedition" that will allow armies of researchers to attack the "genetic roots of disease" and to target "faulty cells". Thus, the map is a precondition for a massive, but expectedly triumphant, military campaign against our common most vicious enemy, Cancer. When Cancer is eradicated, it will become an astronomical constellation, a fate that befalls vanquished foes quite often, of course, in mythical discourse. The statements made at the press conference can easily be read as constituting contemporary instances of mythology, drawing direct lines from legendary feats by heroes of the past (Galileo, Lewis, Watson and Crick) to the final conquest about to be made.

The third "horizon" refers to the 'ethical, moral and spiritual' dimension of the landscape. The map is not an innocent tool, but rather a powerful contrivance that provides us with a completely new type of power. As Clinton phrases it: "Humankind

Genomics, Society and Policy, Vol.5, No.3 (2009) ISSN: 1746-5354

(C) ESRC Genomics Network. 
is on the verge of gaining immense, new power. Genome science will have a real impact on all our lives, will revolutionize [medicine]." But how are we to use this power, represented and made available by this wondrous map? This question calls for a different kind of aide, a different kind of army so to speak, consisting of ELSI experts, about to map the social dimension of the terrain and to fight a different type of enemy, notably "discrimination" (mentioned four times during the gathering).

According to Clinton, besides the evident benefits there are also risks to society which call for a new "partnership", a new campaign, and Prime Minister Blair agrees with that. In order to address the social challenges, those involved in this "great undertaking" have to join forces once more, "on either side of the Atlantic", in a new trans-Atlantic alliance, rounding up troops for a subsequent Crusade. Craig Venter will add to this that "those who will base social decisions on genetic reductionism will be ultimately defeated by science" (my italics).

This same association between map-making and war-making is also invoked in Blair's speech. According to the Prime Minister, the HGP represents "the first great technological triumph of the $21^{\text {st }}$ century". It is "a breakthrough that takes humankind across a frontier and into a new era", opening up the way for "massive advances" where the term "advances" may no doubt be interpreted as instances of progress, but also as a term and a concept belonging to the vocabulary of war: advances into a territory about to be conquered, massive advances against formerly unassailable enemy positions. Thus the map becomes a martial tool, a decisive factor changing the battlefield, exposing enemy lines, making a new and undoubtedly triumphant offensive possible. The map allows us to make the diffuse discrete, to outline 'opportunities' as well as 'threats', and to 'seize' the one and 'minimize' the other.

Collins' subsequent speech draws on a number of metaphors that support and reinforce the atmosphere of religious celebration already invoked by the previous two speakers. The genome is not only presented as "our instruction book", but also as a sacred text now finally revealed to us. Indeed, "We have caught the first glimpse of our own instruction book, previously known only to God." Or, as Collins phrases it elsewhere: "Today we celebrate the revelation of the first draft of the human book of life." It is a book we still have to learn to read properly, of course ("We are to learn how to speak the language of the genome fluently"). Yet, also in his speech, the map metaphor (depicting the human genome as a landscape, the human genome sequence as a map and the HGP as a map-making expedition) is the most dominant one, eclipsing even the book metaphor. Science in general and genomics science in particular are presented as "a voyage of exploration into the unknown", and the penultimate draft of the human genome here presented is seen as an important "milestone" and a "turning point" in the emerging landscape of genomics history. The territory revealed by the HGP is a kind of shared inheritance, something we may appropriate as rightfully belonging to us (where "us" refers to humankind in general), but also as something we have to inhabit wisely and prudently, as if the HGP has revealed the contours of a promised land, given to us as an assignment rather than as a privilege.

Genomics, Society and Policy, Vol.5, No.3 (2009) ISSN: 1746-5354

(C) ESRC Genomics Network. 
Collins also invokes the warfare connotations associated with the central metaphor, although somewhat hidden perhaps. For example, he argues:

As the President has said, we still have much to do. Many tasks lie ahead if we are to learn how to speak the language of the genome fluently. Today is most certainly not the end of genomics, but perhaps it is the end of the beginning.

The latter phrase is a reference to one of Sir Winston Churchill's most famous wartime speeches: "This is not the end. It is not even the beginning of the end. But it is, perhaps, the end of the beginning" (my italics). ${ }^{20}$ And when Collins introduces Craig Venter as the next and final speaker, he says: "Inspired by a life-changing experience as a medical corpsman in Vietnam, Craig charged into the field of human biology". Documents discussing the HGP abound in warfare metaphors, not only in the sense that the HGP is depicted as a decisive battle in the 'war' against cancer, but also in the sense that the 'troops' involved are described in terms of competing armies encountering one another on the battlefield of genomics. For instance: "In June 2000, Venter and Collins reached a fragile truce ... The human genome was officially declared complete (at least in draft form) in February 2001 with the publication of two special issues of Nature and Science, in which the two rival armies of scientists deigned to summarize the breathtaking landscape of the human genome" 21

\section{What is a map?}

The press conference is a highly ambiguous event. On the one hand, it is a celebration of peace and convergence, officially acclaiming that the gene or genome 'war', the arms race between two rival teams, each equipped with their own armaments, their own technologies and tactics (methodologies), has come to an end. On the other hand, new threats are looming on the horizon. But the atmosphere of peacefulness clearly dominates. It is announced that both teams will now continue to work together and publish their results simultaneously. As Clinton phrases it:

Public and private research teams are committed to publishing their genomic data simultaneously later this year, ${ }^{22}$ for the benefit of researchers in every corner of the globe. And after publication, both sets of teams will join together for an historic sequence analysis conference. Together, they will examine what scientific insights have been gleaned from both efforts, and how we can most judiciously proceed toward the next majestic horizons.

This would prove not to be so, however. Shortly after this moment of armistice, the genome war would be fiercely resumed, as if the famous ceremony never took place. In scientific publications, but also in autobiographical accounts, ${ }^{23,24}$ the war would continue with representatives from both teams challenging each other's results, contributions and claims. Still, the scene had shifted from the actual "race" to the realm of historical controversy. Warfare gave way to conflicts of interpretation in retrospect, as also happens in the case of real wars, of course.

Genomics, Society and Policy, Vol.5, No.3 (2009) ISSN: 1746-5354

(C) ESRC Genomics Network. 
Besides this 'after-war', however, and notwithstanding the rhetoric of peace and harmony so abundantly present at the press conference, another campaign is already looming in the minutes. In science and politics, peace is bound to be a temporary state. Interestingly, the implicit but nonetheless disconcerting threat is already built into the central metaphor itself. During the press conference, as we have seen, the map metaphor was used in a rather precise manner, namely in the sense that the human genome was likened to a specific, particular map, ${ }^{25}$ the one drawn up as a result of the Lewis and Clark expedition (1804-1806) funded by the US government headed by President Thomas Jefferson. In order to discern the emerging threat that is present in this reference, we must ask ourselves two questions, namely: what is a map, and: what is so special about this particular map?

In general, one could say that map-making is a technique for organizing and representing information concerning geographical regions and their populations, human or otherwise. ${ }^{26}$ It is one of the many techniques that experts may use for making the diffuse (the real) tangible, accessible and discrete. Maps are conscious simplifications that nonetheless may become increasingly sophisticated and refined. Maps are never finished, as the object they represent is an evolving one, a landscape in a constant state of flux. And as soon as a landscape or territory is mapped, a new dynamics of change is introduced, as maps tend to make certain practices possible with regard to the mapped domain, tend to support, encourage and incite them. A map is therefore never merely a description of a site or landscape, but always also a representation of relationships and a force of transformation in its own right. It is a representation of relationships not only in the sense that relationships between various elements are depicted on the map, but also in the sense that a map allows $u s$ to relate to the part of the world that is thus depicted. It frames and defines our relationship to the world outside and allows us to gain a certain amount of control over this outside territory. It reveals how we (as subject) relate to the depicted landscape (as object), how we 'see' it. In other words, through a map a landscape is allowed to emerge in a certain manner. Maps are powerful tools that combine descriptive and normative functions. They mirror a landscape as reliable and objectively as possible, but at the same time impose a particular kind of order on what in itself remains fluid and unstable and often contested. Quite often, maps give voice to concerns by representing emerging, and perhaps alarming, issues or problems.

At first glance, the Lewis and Clark map seems as accurate and objective as must have been technically possible at the time. Nonetheless it is clear that it was something of a political statement as well, a first decisive step towards the colonization and usurpation of the North-West territories by the eastern States, not least by presenting the landscape as if it were uninhabited and unclaimed (virgin territory). In the Lewis and Clark map, the focus is on the physical properties of the landscape, on rivers and mountains - landscape elements that may either facilitate or hinder the mobility of immigrants. At first glance, everything else (First Nation

Genomics, Society and Policy, Vol.5, No.3 (2009) ISSN: 1746-5354

(C) ESRC Genomics Network. 
inhabitants, animals, plant forms) seems to be virtually ignored or even erased. North America emerges as an abiotic territory.

One has to study the map in much more detail in order to come across a limited number of tiny references to human presence, almost 'in passing', and to discover casually distributed notes conveying a minimum of demographic information (such as: "Wa-pa toone, a Tribe of Sioux 1000 souls"; "Wa-pa too-ta, a band of Sioux 600 souls", etc.). Even the numbers mentioned suggest that inhabitation is marginal compared to the huge numbers of US citizens eager to push the frontiers of Western civilisation further West. Indeed, these minuscule demographic notes, jotted down in the folds and margins of the map, as it were, seem to suggest that these human inhabitants are already on the verge of becoming extinct or at least marginal. Thus, the map, by ignoring or marginalising them, anticipates the virtual decimation of native inhabitants, together with buffalo, prairie grasses and other landscape elements, about to unfold in real life during the decades to come, a process made possible, if not inescapable, by this map. The Lewis and Clark map represented the "Wild West" as a hibernating environment waiting to be awakened, structured, and pacified, ready to be explored and exploited. In depicting the gold-rush region it made the gold-rush possible. Thus the map visualized a relationship between a particular area (the NorthWest territories) and a political entity (the United States of America and its inhabitants) and was guided by a political and ideological program.

In short, maps are never only about landscapes as 'objects', but always also about how we relate to them in terms of politics (borders) or policies (land use, infrastructure, environmental concerns, etc.). A map is always an agenda. And territories are never just 'objects', but rather scenes spread out so that a particular program can be conceived, designed and conducted. The map-making endeavour of Lewis and Clark was a gesture claiming ownership, an exemplification of what Karl Marx came to call "primitive accumulation". Therefore, the conscious and deliberate decision, on June 26, 2000, to present the human genome sequence as a revivification of the Lewis and Clark map, a map that was as notorious as it was famous, was a rather telling and problematic decision, a remarkable gesture. Was genomics also seen as a process of usurpation? And were the politicians, scientists and ambassadors assembling in the East Room on June 26, 2000 actually participating in a ceremony that marked the eve of yet another grand conquest? What kind of practices would be supported and made possible by this new "map"? Was a second gold rush awaiting us? And what would happen to human and animal inhabitants already settled in the human genome landscape?

\section{Summits of promise}

On April 14, 2003, the International Human Genome Sequencing Consortium finally announced the successful completion of the HGP. Ten days later, director Francis Collins and his team published their "vision for the future of genomics research" in Nature, meant as a starting signal for "the era of the genome", but also a highly symbolical gesture, as the publication purposely coincided with the 50th anniversary

Genomics, Society and Policy, Vol.5, No.3 (2009) ISSN: 1746-5354

(C) ESRC Genomics Network. 
of Nature's publication of the landmark paper by Nobel laureates James Watson and Francis Crick describing DNA's double helix. ${ }^{27}$ These two events must be seen in combination, as a pair: one of them presenting the results of 15 years of genome sequencing, the other as an effort to face and anticipate the future from this newly attained position. As Brigitte Nerlich and Lina Hellsten ${ }^{28}$ have pointed out, the completion of the HGP is conceptualised in Collins' paper as the summit of an achievement from which we can see the future "as mapped out on a new landscape". According to Nerlich and Hellsten, in Collins' paper, this new "map" of the human genome region, the vision of an inhabited, structured landscape, has replaced that of "a wilderness to be conquered by genomic settlers" as evoked during the press conference. Let us consider this new "landmark vision" in more detail in order to discern how the map or landscape-metaphor has evolved during these crucial years.

From the perspective of metaphors, the programmatic 2003 paper by Collins et al is remarkably consistent, particularly in comparison with the press conference where, as we have seen, a whole train of more or less conflicting metaphors was evoked. First of all, the history of genomics research is concisely reconstructed as a landscape in which the major achievements (or "landmark events") constitute a "remarkable path" that has brought us from Mendel's discovery (and its subsequent rediscovery) via Watson and Crick and automated sequencing up to where we are now. At this point, the landscape once again emerges as a kind of battlefield, where a legion of talented scientists that has successfully finished its campaign is now lined up again for the next stage, where laboratories are catapulted towards a completely new position, while a cohort of ELSI scholars is called in to fight looming enemies such as "misuse" and "discrimination". ${ }^{29}$ Yet, rather than an open landscape, we are now faced with buildings and emerging infrastructures. The basic topology has shifted. Genome research is no longer envisioned as an army on the move in open and newly charted field. Rather, a solid building has been newly erected in the secured, conquered and domesticated space.

Genomics, Society and Policy, Vol.5, No.3 (2009) ISSN: 1746-5354

(C) ESRC Genomics Network. 


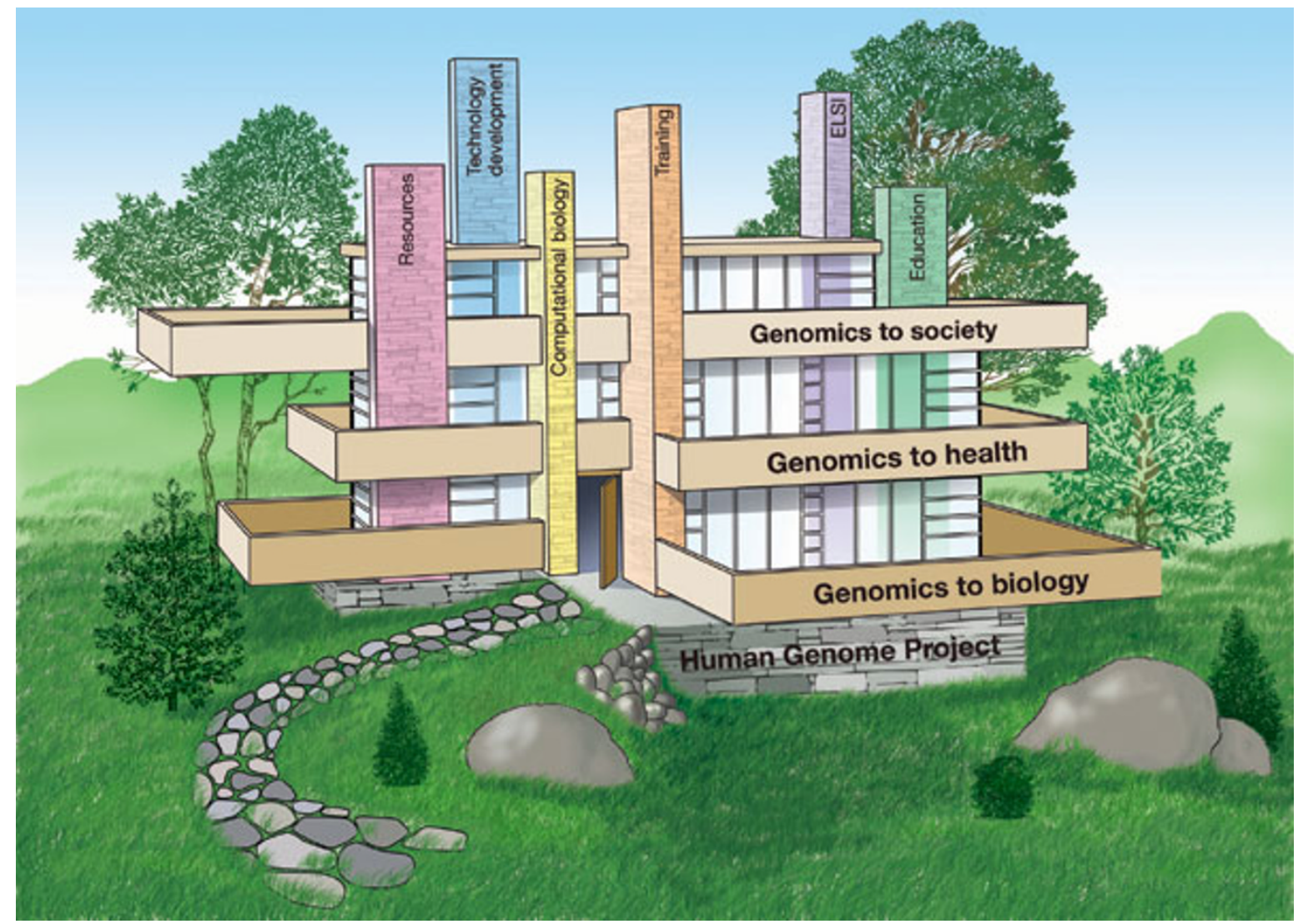

It is a building designed in the style of Frank Lloyd Wright, firmly placed on the HGP as a foundation and consisting of three thematic floors (the horizontal dimension) in combination with six cross-cutting elements (the vertical dimension). From this building, a new phase for genomics research is launched with the objective "to explore the remarkable landscape of opportunity that now opens up before us" The legion of genomics researchers, together with the auxiliary cohort of ELSI researchers, is no longer depicted as pioneers or early settlers, but rather as an army of constructors and "architects" that can build and design the structures and infrastructures (such as databanks, including ELSI databanks) needed to allow us to reap the benefits of the genomics revolution.

\section{Concluding remarks}

During the press conference, as well as in subsequent landmark publications, it became clear that the HGP itself had shaken the metaphorical foundations on which it had initially been built. ${ }^{31,32}$ At the expense of older metaphors (such as the code, the program, the recipe or the blueprint metaphor, that were more or less marginalised or even "discharged"), the idea that the human genome is a kind of landscape, and the human genome sequence a kind of map depicting this evolving landscape, became the dominant metaphor, significantly affecting the manner in which the genomics revolution and its possible consequences for society were framed and communicated. Whereas images such as code, parts list, recipe or blueprint tend to convey a more or

Genomics, Society and Policy, Vol.5, No.3 (2009) ISSN: 1746-5354

(C) ESRC Genomics Network. 
less deterministic conception of the relationship between genome and life, the landscape metaphor has the benefit of allowing the human genome to be presented as a kind of heritage or inheritance that can be placed in the hands of individuals who settle in this landscape as genome entrepreneurs, seizing opportunities, minimizing risks, and allowing genomics information to inform the decisions that determine the course of their lives and their endeavours. It allows us to frame the messages of genomics in terms of promises and possibilities rather than in terms of prefixed fates.

Yet, as already indicated, the use of the map / landscape metaphor has never been a very consistent one. From the perspective of metaphors, the discourse, although structured by the idea of a genome map and a landscape, continued to be 'polluted' by elements and ideas connected with other, older metaphors. During the press conference, for instance, Venter emphasises the immense complexity of both genomes and societies. At the same time, he argues that now for the first time our species can read the chemical letters of its genetic code and that we are about to witness the completion of the human genetic blueprint.

And while Collins eagerly writes about genome landscapes being developed with the help of infrastructures that will allow individuals to settle down and build their lives in this new world of genome information, he also at times reverts to other, less dynamic images and concepts, for instance by allowing the images of the landscape and the map to solidify into blueprints ${ }^{33}$ or into buildings that are to be erected in the confiscated regions. From this perspective, his recent appointment as Director of the National Institutes of Health is a logical next step. The exploring pioneer is finally but irrevocably transformed into a kind of prime bureaucrat of genomics science seated in a central building.

One particular application of genomics, however, is quite a telling one, notably from the point of view of the comparison of a genome sequence to the Lewis and Clark map. In an article in Nature entitled 'The genome of the American West', Emma Marris ${ }^{34}$ remarks that Lewis and Clark during their voyage must have been immensely impressed by the tens of millions of buffalo (Bison bison) still roaming the prairies in massive herds at that time. By the end of the century their number had dropped to a few hundred. Driven to the brink of extinction, they were saved on ranches and in zoos, but these conservation efforts came at a cost: their genomes were "polluted" with cattle genes. Now, the idea has emerged to reverse more than a century of human interference with the buffalo genome, preserving the original bison as purely as possible, as carrier of an "unadulterated genome" 35 (p. 950). According to bison genome expert James Derr, quoted by the author, the fundamental unit of future conservation policies should be the genome rather than the individual. Whereas a particular bison may look like a bison, may resemble the animal's basic image or Gestalt, its identity may be stained in terms of the genome alphabet. In the future, conservation experts will be managing genomes rather than animals, and the protection and purification of the bison genome (as an icon of the American West) may become "a model for conserving other large animals". Thus, genomics is

Genomics, Society and Policy, Vol.5, No.3 (2009) ISSN: 1746-5354

(C) ESRC Genomics Network. 
changing the landscape once again, but in a rather paradoxical manner. Genomics may become a Lewis and Clark map in reverse, in the sense that it assists us in reconstructing parts of the landscape depicted on it. In other words, the map is now used for purposes of reconstruction rather than destruction. And the bison genome may become just one particular 'landscape element' in a genomics-based offensive to restore the prairie landscapes of former times in terms of flora and fauna, revivifying the biota and the ecosystems that were decimated and destroyed in the past by a civilisation that employed the Lewis and Clark map to launch its ecological and demographical deluge. Rather than waging a war against cancer at the frontiers of biomedical science, genomics will then emerge as a 'tool kit' for a restoration campaign.

\section{Acknowledgments}

This article builds on research that is part of the Research Programme of the Centre for Society \& Genomics, funded by the Netherlands Genomics Initiative. It profited from comments and discussions that emerged in response to presentations by the author on various occasions, notably at the CSG Conference organized by Maud Radstake on genomics images (November 2007) and at the EGN International Conference 'Mapping the Genomic Era: Measurements and Meanings' at Cardiff (October 2009).

\footnotetext{
${ }^{1}$ Centre for Society and Genomics, Radboud University Nijmegen. h.zwart@science.ru.nl

${ }^{2} \mathrm{http}$ ://www.genome.gov/10001356

${ }^{3}$ Cf. "Now is the winter of our discontent / Made glorious summer..." etc. (Richard III, Act I, scene 1).

${ }^{4} \mathrm{Cf}$. the titles of important historical accounts concerning the human genome sequencing efforts, notably Robert Cook-Deegan's The Gene Wars and James Shreeve's The Genome War. R. CookDeegean. 1994. The Gene Wars: Science, Politics and the Human Genome. New York. Norton. J. Shreeve, J. 2004. The Genome War. How Craig Venter tried to capture the code of life and save the world. New York. Knopf.

${ }^{5}$ At a workshop in Santa Fe on how to raise funds for the HGP, in the presence of Senator Pete Domenici and other key players in US science politics, it was argued that "a century from now, as history books are written, the big projects that were important in this century will be the genome project, and after it possibly space, and then the atomic bomb" (Cook-Deegan op.cit. note 4, p. 152). In an article outlining the HGP's basic objectives, James Watson declared, as director of the National Center for Genome Research, that "although the final monies required to determine the human DNA sequence will be an order of magnitude smaller than the monies needed to let men explore the moon, the implications of the HGP for human life are likely to be far greater" (J.D. Watson. The Human Genome Project: Past, Present and Future. Science 1990; 248: 44.) And when Francis Collins, at an April 1993 press conference, confirmed his appointment as Watson's successor, he claimed the HGP to be "more important than putting a man on the moon or splitting the atom" (K. Davies. 2001. Cracking the Genome. Inside the Race to Unlock Human DNA. Baltimore and London: John Hopkins University Press).
}

Genomics, Society and Policy, Vol.5, No.3 (2009) ISSN: 1746-5354

(C) ESRC Genomics Network. 
${ }^{6}$ R. Shapiro. 1991. The Human Blueprint. The Race to Unlock the Secrets of Our Genetic Script. New York: St. Martin's Press.

${ }^{7}$ D..J. Kevles \& L. Hood (eds.) 1993. The Code of Codes: Scientific and Social Issues in the Human Genome Project. Cambridge: Harvard University Press.

8 "The sequence of human DNA is the reality of our species ... we have come a long way in our effort to understand cancer. The next generation can look forward to exciting new tasks that may lead to a completion of our knowledge about cancer, closing one of the most challenging chapters in biological research". R. Dulbecco et al. A Turning Point in Cancer Research: Sequencing the Human Genome. Science 1986; 231: 1056.

${ }^{9}$ W. Gilbert. A Vision of the Grail. In: Kevles \& Hood op.cit. note 7; Cook-Deegan op.cit. note 4, p.88; Davies op.cit. note 5, p. 12.

${ }^{10}$ H. Zwart. Genomics and Self-knowledge. Implications for Societal Research and Debate. New Genetics and Society 2007; 26 (2): 181-202.

${ }^{11}$ H. Zwart. Understanding the Human Genome Project: A Biographical Approach. New Genetics and Society 2008; 27: 353-376.

${ }^{12}$ H. Zwart. 2009. Genomics Metaphors and Genetic Determinism. In NewVisions of Nature:

Complexity and Authenticity. J. Keulartz, M. Drenthen \& J. Proctor (eds.). Dordrecht / New York: Springer: $155-172$.

${ }^{13}$ While Clinton, Collins and Venter gave their speeches, a screen resembling a blackboard was on display right behind them, on which, apparently in chalk, the slogan "Decoding the book of life" was written.

${ }^{14}$ B.J. Culliton. Human Gene Maps: A First Step Toward Genetic Engineering. Science News 1970; 98 (8/9): 176-177.

${ }^{15}$ Gilbert, op.cit. note 9 .

${ }^{16}$ In Gilbert, ibid. Although the term genome mapping is used and various types of genome maps (genetic map, physical map, cosmid map) are distinguished, it is taken basically as a technical term. Gilbert's favourite human genome metaphor, as already mentioned, was the Grail. And when it comes to outlining the meaning of the human genome sequence for human existence, he compares the human sequence to "a thousand thousand-page telephone books" (p. 84) whose content is about to become available on a Compact Disk (p. 96).

${ }^{17}$ A striking example of the use of the map metaphor in support of human genome sequencing is recorded by Cook-Deegan, op. cit. note 4. He mentions that in 1988 John Dingell, chairman of the House of Energy and Commerce Committee of the US Congress, in order to fuel support for the genome project, likened the situation to "the problems facing Congress a century earlier, when trying to integrate the various surveys of land and coastal regions in anticipation of the second opening of the American West" (p. 153).

18 "The combined wisdom of biology, chemistry, physics, engineering, mathematics and computer science, public and private; more than 1,000 researchers across six nations have revealed nearly all 3 billion letters of our miraculous genetic code."

${ }^{19}$ Venter likewise seems to suggest that his work was done in the service of the presidency when he points out that his Celera team sequenced the human genome at a distance of no more than 18 miles from the White House.

${ }^{20}$ Winston Churchill. Speech at the Lord Mayor's Luncheon at Mansion House, London, 10 November 1942.

${ }^{21}$ Davies, op.cit. note 5, p. xv.

${ }^{22}$ The actual publication would take place somewhat later of course, in February 2001.

${ }^{23}$ J. Sulston and G. Ferry. 2002. The Common Thread. A Story of Science, Politics, Ethics and the Human Genome. New York. Bantam / Corgi.

${ }^{24}$ J. C. Venter. 2007. A Life Decoded. My Genome: My Life. Viking Penguin: New York.

${ }^{25} \mathrm{http}: / / w w w . l i b . u t e x a s . e d u / m a p s /$ historical/lewis_clark_nima.jpg

${ }^{26}$ Many definitions of map have been given, such as: "A map is a graphic representation or scale model of spatial concepts. It is a means for conveying geographic information. Maps are a universal medium for communication, easily understood and appreciated by most people, regardless of language or

Genomics, Society and Policy, Vol.5, No.3 (2009) ISSN: 1746-5354

(C) ESRC Genomics Network. 
culture. Incorporated in a map is the understanding that it is a 'snapshot' of an idea, a single picture, a selection of concepts from a constantly changing database of geographic information." http://academic.emporia.edu/aberjame/map/h_map/h_map.htm

${ }^{27} \mathrm{http}: / /$ www.genome.gov/11006929

${ }^{28}$ B. Nerlich and L. Hellsten. L Genomics: Shifts in Metaphorical Landscape Between 2000 and 2003. New Genetics and Society 2004; 23 (3): 255-268.

${ }^{29}$ F. Collins et al. A Vision for the Future of Genomics Research. A Blueprint for the Genomic Era. Nature 2003; 422: 835.

${ }^{30}$ Ibid, p. 847.

${ }^{31}$ Nerlich and Hellsten, op.cit. note 28 pp. $255-268$.

${ }^{32}$ Zwart op.cit. note 12, pp.155-172.

${ }^{33} \mathrm{Cf}$. for instance the subtitle of his 2003 paper.

${ }^{34}$ E. Marris The Genome of the American West. Nature 2009; 457: 950-952.

${ }^{35}$ Ibid, p. 950.

Genomics, Society and Policy, Vol.5, No.3 (2009) ISSN: 1746-5354

(C) ESRC Genomics Network. 